\title{
AN ADP-BASED MAPPING SYSTEM FOR INVESTIGATIONS OF LAYERED INTRUSIONS IN KOILLISMAA AREA, NORTH-EASTERN FINLAND
}

\author{
Rauno Hugg, Markku Isohanni, Seppo Koivumaa, Martti Löytynoja and Tauno Pinrainen
}

\begin{abstract}
Hugg, Rauno; Isohanni, Markku; KoivumaA, Seppo; Löytynoja, Martit; and Pirrainen, Tauno 1975: Investigations of layered intrusions in Koillismaa, north-eastern Finland by an ADP-based mapping system. Bull. Geol. Soc. Finland 47. 155-166
\end{abstract}

\begin{abstract}
A research model for basic intrusions, based on automatic data processing, is presented. The data material is composed of field and microscope observations of the chemical and mineral composition of the rocks, and of observations on the chemical composition of the minerals. All this material is used to produce geological profiles, which are the main means of representing

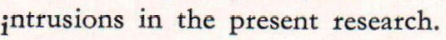

Rauno Hugg and Tauno Piirainen, Koillismaa Research Project, Department of Geology, University of Oulu, SF-90100 Oulu 10, Finland.

Markku Isobanni, Rautaruukki Oy, Prospecting Department, SF-90100 Oulu 10, Finland.

Seppo Koivumaa and Martti Löytynoja, Koillismaa Research Project, Institute of Data Processing, University of Oulu, SF-90100 Oulu 10, Finland.

\section{Introduction}

In 1971 the Koillismaa Research Project was established in the Departments of Geology and Geophysics of the University of Oulu in order to explore the critical ore areas of Koillismaa. This project was supported by Government funds directed towards basic research in connection with ore exploration in northern Finland. In addition to the above mentioned departments the Institute of Data Processing and the Institute of Electron Optics of the University of Oulu have also participated in the project.
The research area comprises the basic intrusive belt from Syöte to Näränkävaara close to the eastern border of Finland (Enkovaara et al. 1953; Matisto 1958; Fig. 1). In the intrusives features typical of basic layered intrusions are found (Wager \& Brown 1967), and ore showings typical of layered intrusions are also present. The belt forms a most interesting example of basic magmatism and related ore forming processes (Ohenoja 1968; Piirainen \& Juopperi 1968; Juopperi 1972; Piirainen et al. 1974). The genesis, movements and crystallization of basic magma form a chain of events which it is possible 


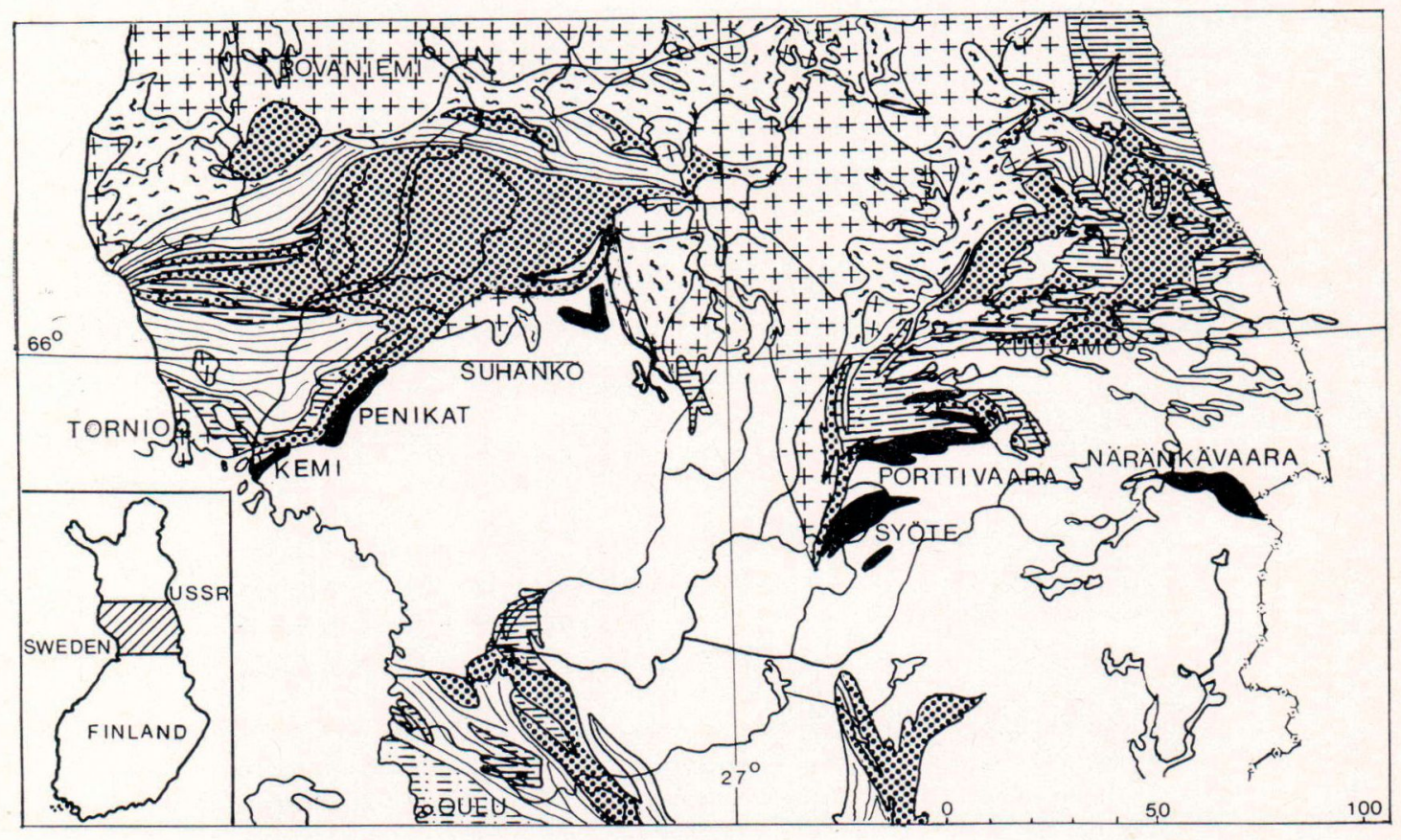

EGEND

SVECOKARELIAN: ++ OROGENIC GRANITE $\cdots S$ MIGMATITE E: QUARTZ-FELDSPAR SCHIST BASIC INTRUSIVE EITE AND MICA SCHIST BASIC VOLCANICS
QUARTZITE

PRE SVECOKARELIAN: $\square$ GRANITE GNEISS

Fig. 1. The location and geology of the research area (modified after Simonen 1960)

to trace only by exact geological mapping and petrological, mineralogical and petrogeochemical investigations. In this way wide, multivariate data materials are gathered whose manipulation by conventional methods is a labourious task. ADP therefore offers facilities for carrying out this program.

These were the factors behind the planning of the Koillismaa project. The main aim was to obtain answers to the questions related to the problematics of the above discussed basic magmatism, with the emphasis on forwarding the discovery of ore deposits not only in the basic intrusive belt under investigation, but also in other basic intrusions elsewhere.

The development of ADP methods has formed an essential part of the research aims of the Koil- lismaa project. As a result of this work the following ADP based geological research method has been developed for application to the basic layered intrusions in this specific case.

\section{The geological basis of the research}

\section{Geological mapping}

On the basis of geological mapping of the layered intrusions carried out by the Outokumpu Oy and Rautaruukki Oy companies it is known that certain horizons in the intrusions are very clear and easily traced along the strike of the layering. The dip of the layering varies little 


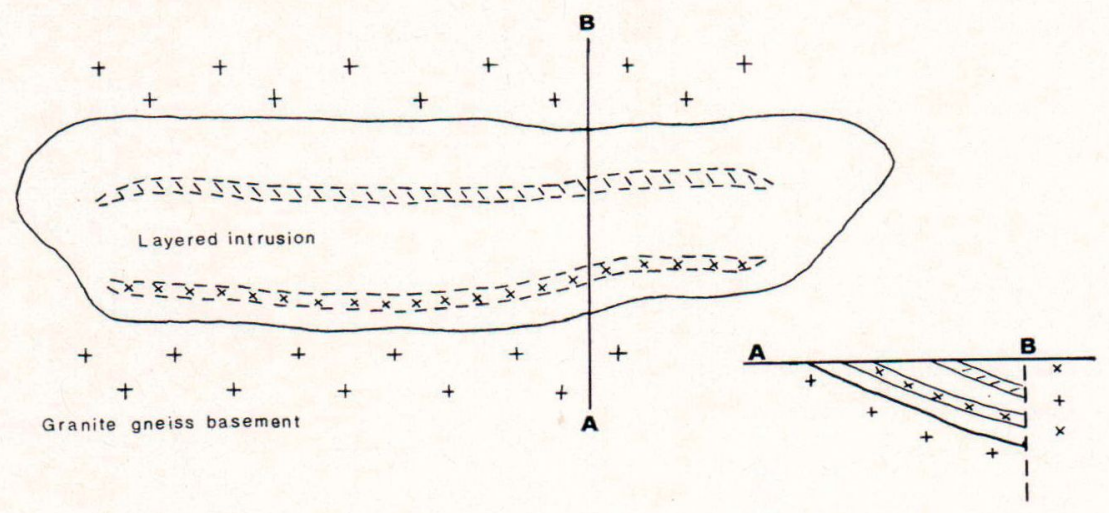

Fig. 2. A schematic picture of a layered intrusion in Koillismaa.

within the cross section of each individual intrusion (Fig. 2). Thus the use of a mapping method which presupposes certain continuities was considered valid. It was decided to carry out the geological mapping of the intrusions along profiles crossing the intrusions thus leaving the gaps between profiles with lesser attention, unless there was any specific reason for a closer examination of them.

The geological mapping in this special case was carried out so that the observation points formed a line that is almost perpendicular to the strike of the layering. Naturally, keeping in mind the sparse outcrop density in Koillismaa, straight observation lines cannot be created, instead a rather winding row of points is obtained which forms a $0.5-1 \mathrm{~km}$ wide zone across the rock formation under investigation (Fig. 3). The lateral extent of each individual observation point within the zone varies from a few metres to approximately 100 metres depending on the size and shape of the outcrop. However, the observation is written down on the mapping document as a single point. The intention is that the observation zones are located across the rock formation to be mapped by utilizing all the available preliminary information, such as aerial photographs, topographic maps, geophysical data etc. The distance between the profiles varies so that, for example, across an approximately $30 \mathrm{~km}$ long layered intrusion seven profiles are mapped, the reciprocal distances being $2-6 \mathrm{~km}$. It is worth emphasizing that the row of observation points does not have to be on a straight line in order to make a profile, but the observation zone can be located in any normally mapped area whose structure is suitable for this type of research.

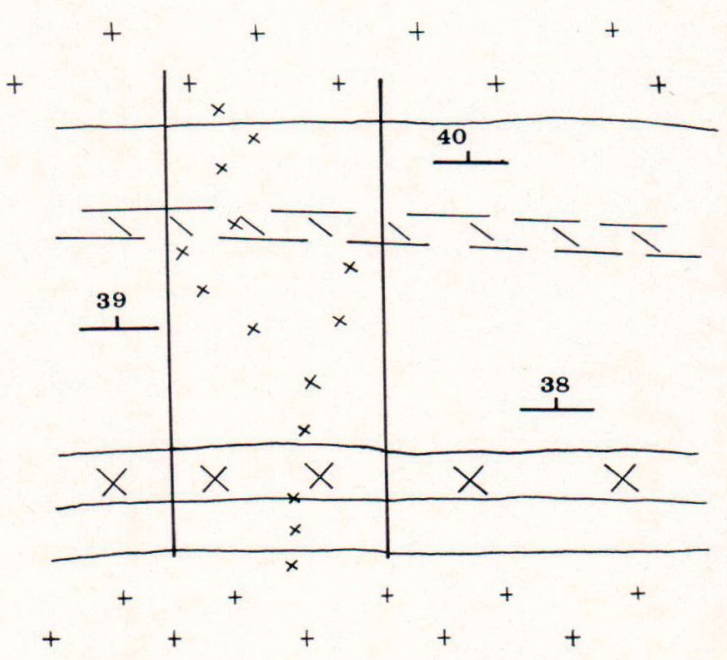

Fig. 3. An observation zone across a layered intrusion. 
The construction of a profile from the observed data

After the observation zone is established a point is chosen on it through which a vertical plane is placed. The observation points are projected on this plane in the direction of the strike of the layering or lamination (Wager \& Deer 1939). The direction of this vertical plane is determined by tectonic observation so that it strikes perpendicularly to the layering, supposing that the plunge is horizontal, and the observation points are projected perpendicularly to the vertical plane. If there are essential differences in the strike of the layering within the observation zone, the zone is divided into sub-zones and a vertical plane is placed across each individual sub-zone on which the observations of the corresponding sub-zone are projected (Fig. 4). In such a case the observations are thus projected on a broken plane, ie. on a plane that is composed of two or more parts.

As changes in the topography of the terrain are noticeable in Koillismaa and as, on the other hand, the dips of the layering are gentle $\left(30^{\circ}-\right.$ $40^{\circ}$ ), any errors caused by these factors have to be corrected for in connection with the projections on the vertical plane. This is done by choosing a horizontal level, the so called artificial ground level, on which the observation points are projected in the direction of the dip of the layering/ lamination (Fig. 5). With this method the distortions caused by topography are compensated for and the resulting order of layering on the constructed line equals the true one.

If desired, the profile line can be turned so that it strikes perpendicularly to the layering (Fig. 6).

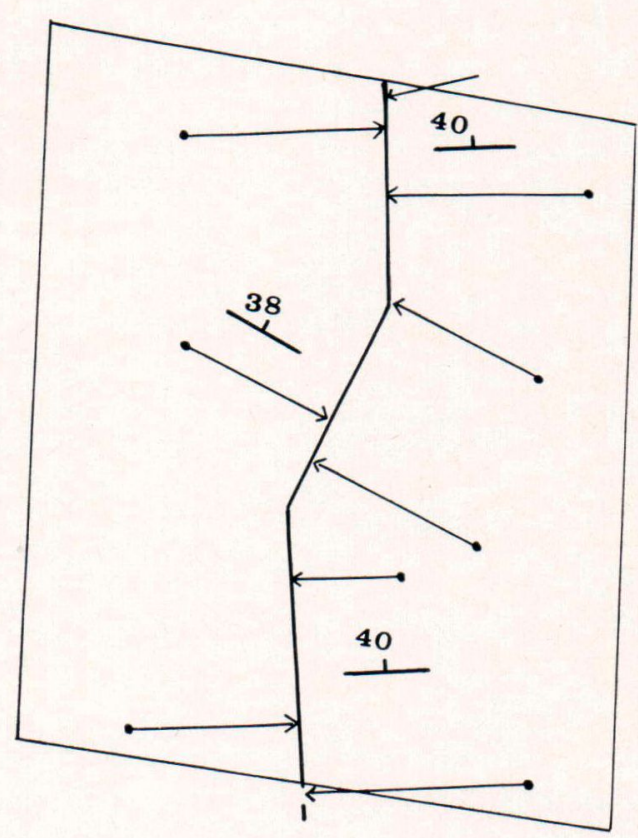

Fig. 4. The projection of observation points on the vertical broken plane.

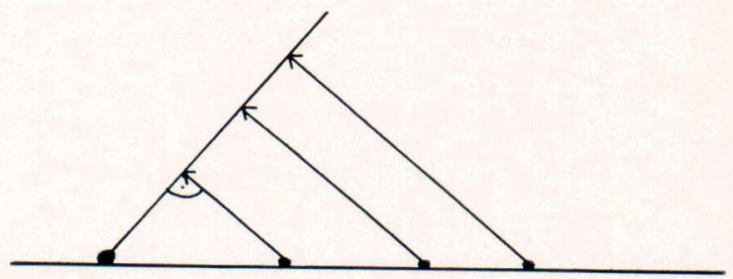

Fig. 6. The profile line turned perpendicular to the assumed layering.

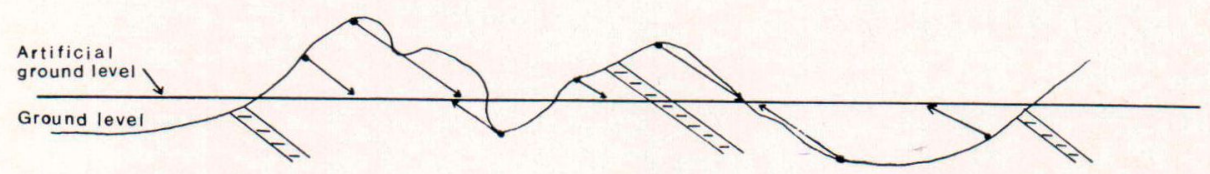

Fig. 5. The projection of observation points on the artificial ground level. 


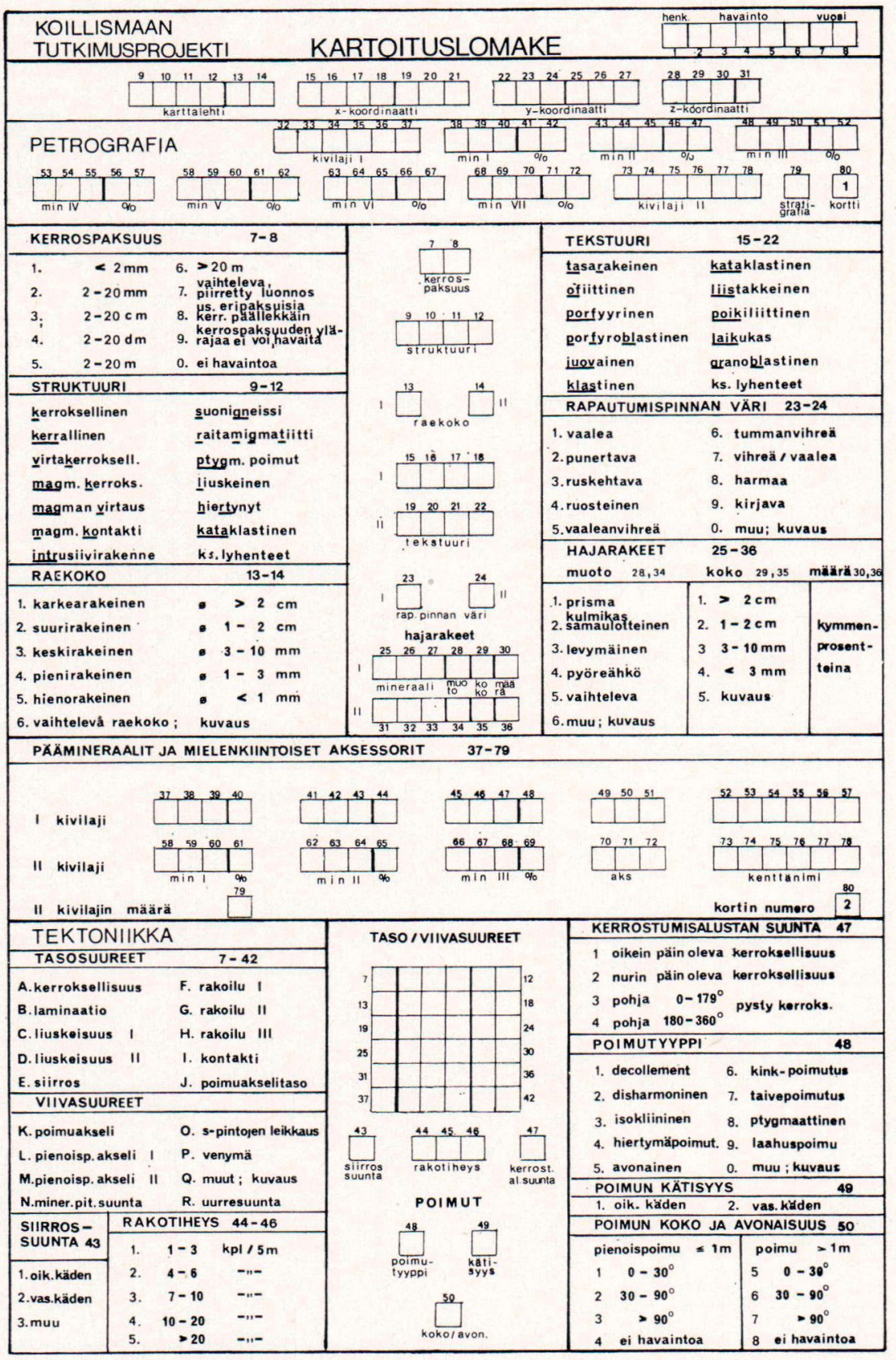

Fig. 7. The mapping document of the Koillismaa project. 


\section{The collection of data for the profile programs}

The geological field observations must contain sufficient information that the construction of the profiles is technically feasible. A form for geological mapping, referred to as the mapping document, was drawn up to meet the requirements of the Koillismaa project (Vuorimiesyhdistys 1973, Fig. 7).

The mapping document contains firstly an ID (identification) part (card 1, columns 1-8) which codifies the observation point and the information gathered from it in the field. Then comes information connected with the location of the observation point: 1:20000 scale map sheet number, and the $\mathrm{X}, \mathrm{Y}$ and $\mathrm{Z}$ coordinates to an accuracy of $10 \mathrm{~m}$ (card 1, columns 9-31).

In addition to this information the strike and dip of the prevailing layering/lamination of the zone must be recorded fairly accurately (card 3, columns 7-42, A and B). Rock formations that cut the layering/lamination, eg. dykes, are not illustrated when the profiles are produced, but are collected in a separate data file which can be used afterwards, if necessary.

Rock specimens gathered during the geological mapping are usually subjected to various different laboratory examinations the results of which can be presented on the profile. The chemical compositions of the rock are obtained as AAS assay results, or as semiquantitative XRF results. The chemical compositions of the minerals are determined by electron microprobe, and by microscope examinations that also gives the qualitative and quantitative mineral composition of the rock.

\section{The ADP system}

Data files

In the ADP system employed in the Koillismaa project the data have been filed in several independent data files. The decision to do this then made it possible to plan and set up data files which meet the objects of the project, with regard to their structure and usability, in a relatively short time.

In the profile representations of the layered intrusions both the field observations from the geological mapping and the petrogeochemical assay results are used. These data have been filed in separate data registers, ie. data registers of field observations, AAS analyses, XRF analyses, electron microprobe results, and thin and polished section description results. In producing the profile it is necessary to combine all the data of a certain geographical area. To make this possible every logical record of every data file contains an unambiguous identification code by which the data pertaining to one and same observation point can be connected together.

The data of structural geology are punched on to cards on the basis of the mapping document. The data are double checked, the compass readings are converted to true geographic direction angles, the data are sorted by map sheets, and filed on magnetic tapes as card images.

The petrogeochemical data are punched on to cards with codes of variables (Fig. 8). This allows for varying lengths of records and data terms. The code is a combination composed of $1-3$ letters and/or numbers, and its numerical equivalent is used in most of the programs of the profile program package as the identification of the variable. The assay data are recorded in packed form on magnetic tapes sorted both by map sheets, and by the code numbers within the records.

AW0145 IITIT .18 ALT 14.15 FTT 6.50 MNT .155 MGT 14.70

AW0145 II1CAT 8.96 NAT 3.04 KAT .29 VAT .007

AW0145 II1 CRT .066 COT .007 NIT .049

AW0145 II1 CUT .014 ZNT .007 PBT 0

AW0145 II2 TIT .22 FTT 10.05 ALT 11 MNT .18 MGT 21.02

AW0145 II2 CAT 6.5 NAT 1.67 KAT .2 VAT .001

Fig. 8. An example of the punching of geochemical data on the data cards. 
For the profile program the data files are transformed to matrix form (to the so called standard data file). In this temporary data file the numbers are in binary form, and all the variables have fixed positions. At the beginning of the data file there is a descriptive section in which the number, codes, positions, lengths and types of variables of the data file are given. The data are in this matrix form throughout most of the intermediate phases of the profile program package.

\section{Programs}

The profile program package is composed of several separate programs of which each one carries out a limited part of the total function. The interprogram data are transferred from one program to another by disc files that are in standard form. Thus the programs are independent. Usually, when the profiles are calculated, it is not necessary to run all the programs of the package, the number used depends on the characteristics of the research area and on the desired results.

The programs contained in the profile data package can generally be divided into the following types:

- Data file processing programs by which the data can be transformed into the desired form, and by which data files, that are in the same form, can be combined.

- Search and sorting programs by which

a) observations that meet a given criterion can be picked up from the input data

b) relevant variables can be selected from the set of all variables included in the file

c) records can be sorted by a given variable

- Projection programs that transfer the obsevation points on the profile plane/line.

- Auxiliary programs that can be used to make up the required parameter files and to determine the strike of the profile line.

- Output programs which are composed of a $21 \quad 7352-75$

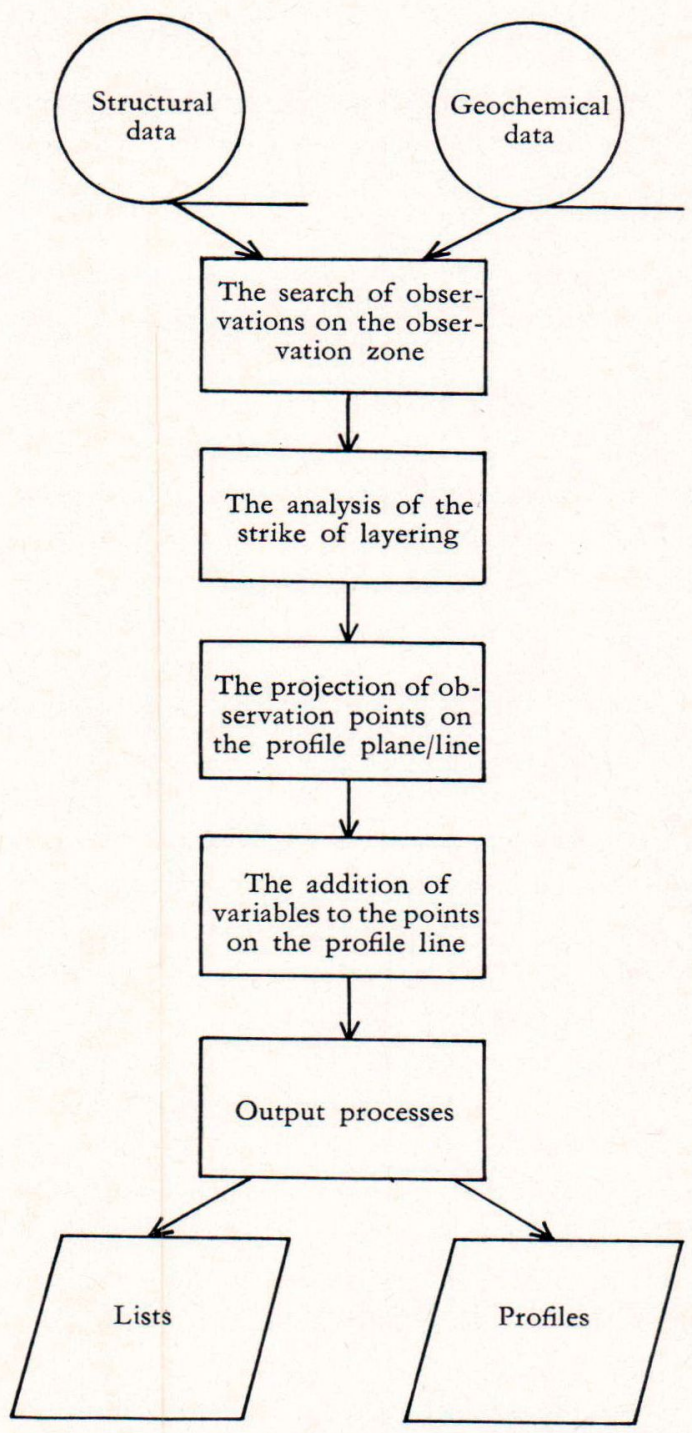

Fig. 9. The main phases in producing the profile.

graphic plotter program, a line printer plotting program and a listing program.

The main stages in forming the profile are shown in Fig. 9. It is not necessary to analyse the strike of the layering if the strike is already known for the area. The general strike of the layering in the research area and the strike of the profile line are always manually determined by a geologist. The projections of the observation 
points are done by coordinates and by the strike and dip of the layering.

The following description outlines the operation of the main phases of profile formation in more detail. The classification of the phases has not been taken to the level of individual programs so the processes mentioned in the following may be composed of several different programs.

Firstly, the observations from the map sheets covering the research area are transformed to the standard form required by the profile program package. The search program picks out the observations that are relevant to the research area by means of the coordinates of the corner points given by the user. The area can be a polygon of any form provided that its angles do not exceed 180 degrees. The next step, if necessary, is an analysis of the strike of the layering. This is done so that the program package, on the basis of observations of the strike of the layering in the area, can make a suggestion for the strike of the profile line, transfer the observation points to this line, and list the corresponding observations proceeding along the line.

The projection of the observation points is done in two steps as indicated in Figs. 4-6. If the profile is not straight line, a number of the observation points may be so located that their projection can not be made automatically. The locations of such points have to be determined by the user.

As a result of the preceding processes a disc file is obtained that contains the locations of the observation points of the area on the profile line and the distances of these points from the starting point of the profile, measured either along the artificial ground level or a line running perpendicularly to the layering. In addition, the records have been ordered with reference to increasing distance from a given base point.

The data of structural geology and geochemical observations for the area are connected to the points on the profile line by the identification code. At first, separate data files are formed for

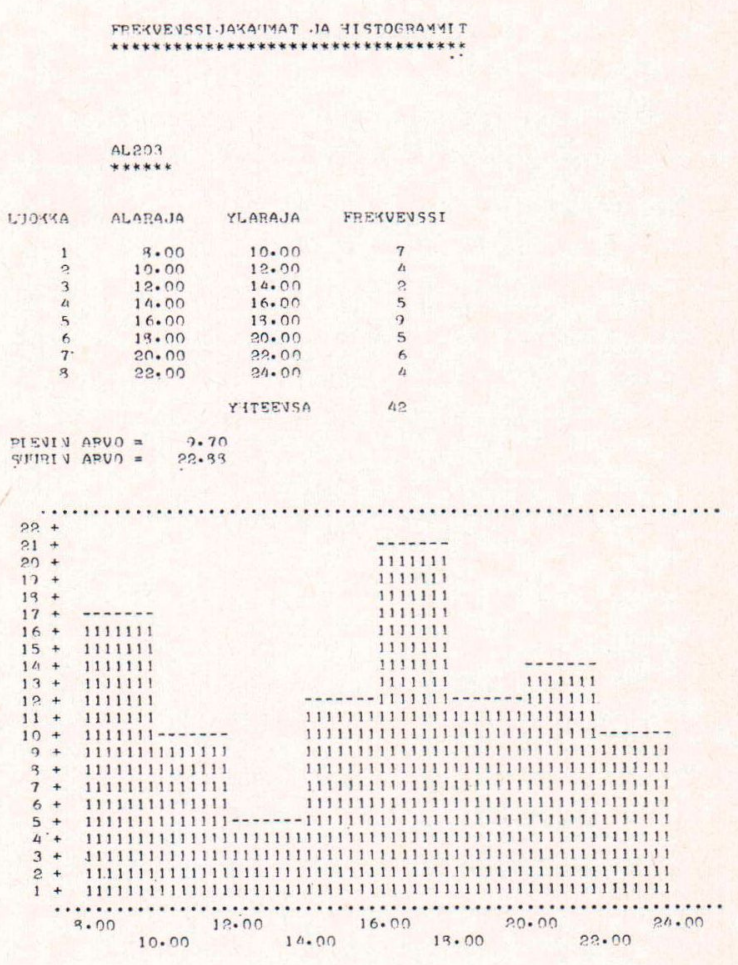

Fig. 10. A histogram of $\mathrm{Al}_{2} \mathrm{O}_{3}$ distribution.

both of the data groups, but later a combined data file can also be produced from the desired variables of these data groups. In addition, new variables can be formed from the ratios of the geochemical assay variables. Data files thus obtained can then be used to print out the profiles. This can be in the form of either line printer point plottings or graphic plotter pictures of A 3 size $(297 \times 420 \mathrm{~mm})$. In addition, the final listings can be printed out from the values of desired variables on the profile.

\section{The use of the profile program package}

The program package has been designed solely for a time sharing environment. The programs 


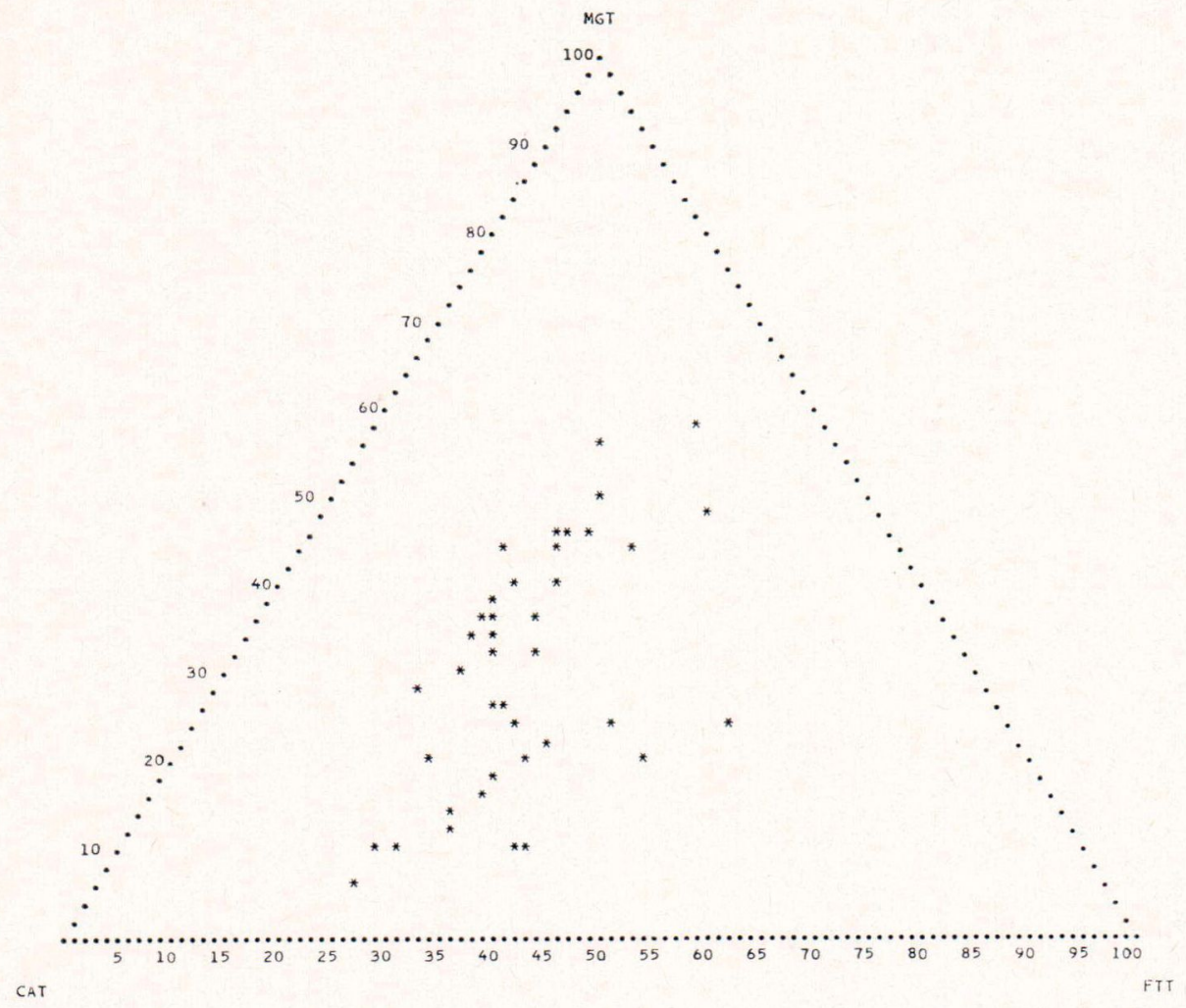

Fig. 11. A $\mathrm{CaO}-\mathrm{MgO}-\mathrm{Fet}_{\text {tot }}$ ternary diagram.

ask the user for the required parameters and the production of profiles is an interactive co-operation between man and computer. The object has been to make the program package as clear and easy to use as possible so that it can be operated without the help of ADP educated personnel.

In all, approximately 30 separate programs belong to the program package. The programming language is Fortran IV, but some subprograms are also based on the assembler language (DAP-16).

\section{Examples of output}

A few examples of the output of the profile program package are appendixed (Figs. 10-13) in which a line printer has been used and the input data is composed of material obtained from one profile across a layered intrusion.

- Fig. 10 is a histogram of $\mathrm{Al}_{2} \mathrm{O}_{3}$ distribution. - Fig. 11 is a $\mathrm{CaO}-\mathrm{MgO}-\mathrm{Fe}_{\mathrm{t} \text { ot }}$ ternary diagram.

- Fig. 12 describes the variations of sulphide forming elements in a layered intrusion.

- Fig. 13 indicates the variation of the variable pair $\mathrm{MgO}-\mathrm{Fe}_{\text {tot }}$ in a straight angle coordination.

The figures described above $(10-13)$ provide only a few examples of the output possibilities of the profile program package. With this program package it is possible to retrieve graphically the changes of any variables that have been either recorded in the field or analysed in the laboratory. Moreover, it is possible to appreciate visually the interdependence of different variables in several ways. Later on, it will be possible to plot tectonic 
KOILLISMAAN TUTKIMUSPROJEKTI

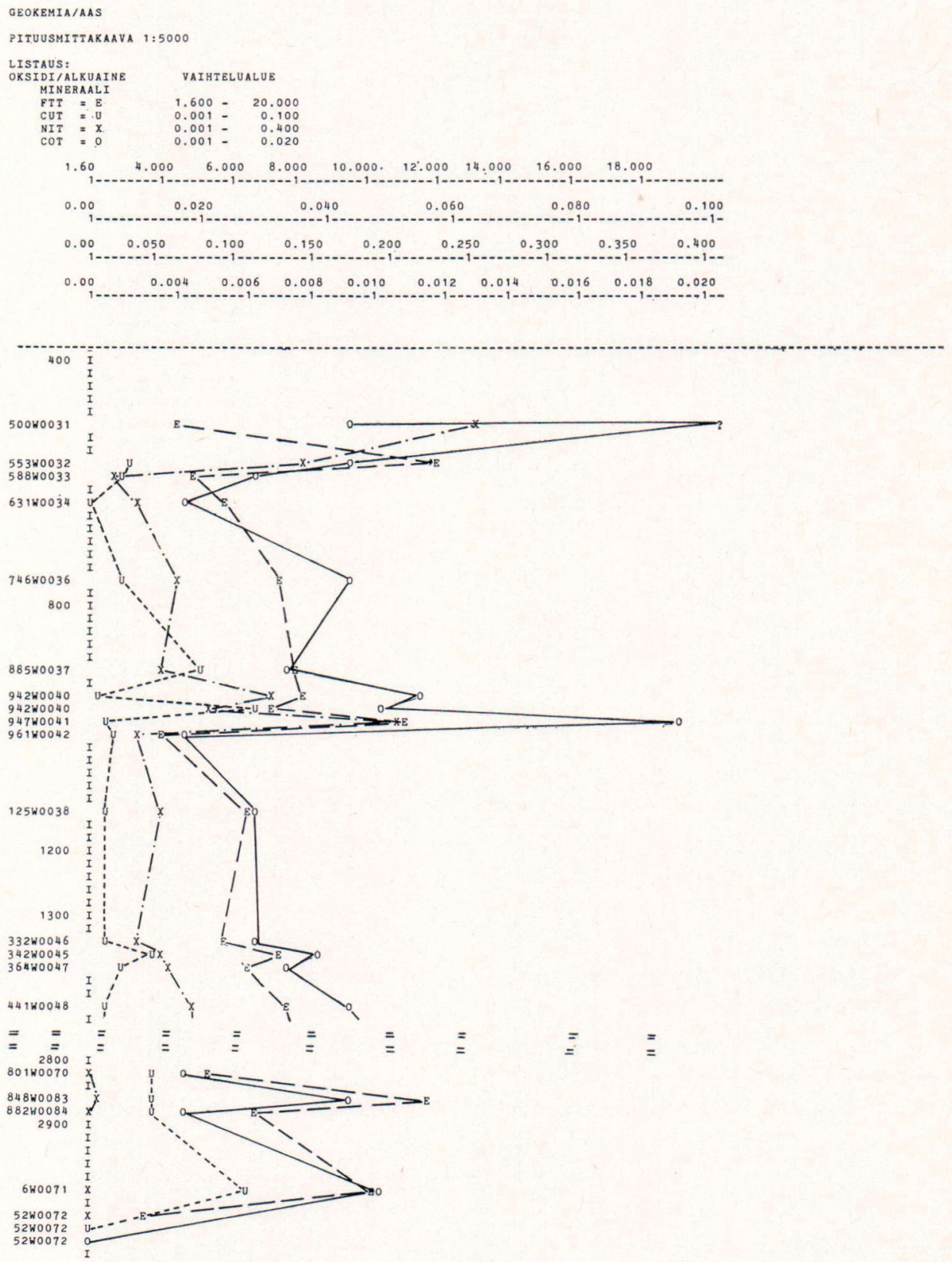

Fig. 12. The variation of sulphide ore forming elements in a layered intrusion. 
MIUTTUJAPARI Y YAVAINVOT KOTRIVAATISTOSSA

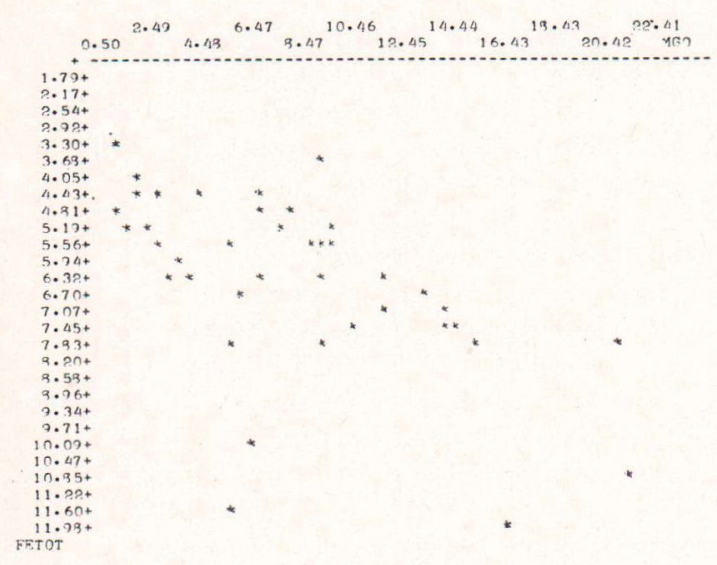

Fig. 13. The variation of the variable pair $\mathrm{MgO}-\mathrm{Fet}_{\mathrm{t}}$ in straight angle coordination.

diagrams and different tectonic element maps. In the final output form, a drum plotter attached to the computer will be used which will essentially improve the appearance and the accuracy of the prints in comparison with the present ones.

\section{The objects of the profile program package}

At the first stage of the profile program package variations in the strike of the layering in certain rock formations can be read visually as far as the cross section of this formation is concerned. All the above mentioned data files can be used as the input data for this program package, and so it is even possible to search visually for correlations between several different variables. Moreover, statistical methods can be applied that considerably widen the field of possibilities for its use.

It is intended by means of this program package, to clarify possible former interrelationships of layered intrusions, which are, at present, separated from one another, their course of crystallization, the magmatic currents and pulses, etc. Above all, it should solve some of the problems of the crystallization of basic magma and the related ore forming processes. One of the objects of this program package will be to create a three dimensional block diagram by means of which it will be possible to examine more quantitatively the course of crystallization and the ore forming processes. By that time we also hope to be able to include in the method the empirical results of research on crystallization and ore forming processes in layered intrusions.

The use of the profile program package is not limited only to the research of layered intrusions, but can also be applied to any rock formation having a certain degree of continuity. 


\section{REFERENCES}

Enkovaara, A., Härme, M. and Väyrynen, H. (1953) Kivilajikartan selitys, C5-B5 Oulu-Tornio. English summary: Explanation to the map of rocks. General Geological map of Finland, 1: 400000.

JUopperr, A. (1972) Porttivaaran emäksisen intrusiivin kiteytyminen ja siihen liittyvän titaanirautamalmin synty Fe:n, Mg:n, Ti:n ja V:n jakaantumisen valossa Fil. Lic. thesis. Manuscript at the Department of Geology, University of Oulu, Finland.

Matrsto, A. (1958) Kivilajikartan selitys, D5 Suomussalmi. English summary: Explanation to the map of rocks. General Geological map of Finland, 1: 400000.

Ohenoja, V. (968) Porttivaaran-Kuusijärven alueen kallioperä. Master's thesis. Manuscript at the Dep. of Geol., Univ. of Oulu, Finland.

Pitrainen, T. and Juopperi, A. (1968) Die Titaneisenerzlagerstätte von Porttivaara und Ihre Entstehung. Nordia 5.
Pitrainen, T., Hugg, R., Isohanni, M. and Juopperi, A. (1974) On the geotectonics and ore forming processes in the basic intrusive belts of Kemi-Suhanko, and Syöte-Näränkävaara, northern Finland. Bull. Geol. Soc. Finland 46: 93-104.

Simonen, A. (1960) Pre-Quaternary rocks in Finland. Bull. Comm. Géol. Finlande 191.

Vuorimiesyhdistys-Bergsmannaföreningen R.Y. (1973) ATK-menetelmien käyttö kallioperäkartoituksessa. Tutkimusseloste n:o 39. English Summary.

WAger, L. R. and Deer, W. A. (1939) Geological Investigations in East Greenland, Pt. III. The Petrology of the Skaergaard Intrusion, Kangerdlugssuaq, East Greenland. Medd. om Grønland, 105: 1-352.

WAGER, L. R. and Brown, G. M. (1967) Layered igneous rocks. Oliver and Boyd. Edinburgh, London.

Manuscript received, February 27, 1975. 